\title{
SOCIAL MEDIA AND LEARNING OF BUSINESS SUBJECTS IN SENIOR SECONDARY SCHOOLS IN IKORODU LOCAL GOVERNMENT AREA OF LAGOS STATE
}

\author{
Fasae, Felicia Bosede Kehinde \\ Department of Office and Information Management Bamidele Olumilua University of Education, \\ Science and Technology, Ikere-Ekiti
}

Article DOI: https://doi.org/10.36713/epra5611

DOI No: 10.36713/epra5611

ABSTRACT
This study investigated social media and the learning of business subjects in some selected secondary schools in
Ikorodu Local Government Area of Lagos State. The research design for the study was survey of the descriptive type.
Five schools were randomly selected from which 100 students were further randomly selected, forming the sample for the
study. A self-structured close ended questionnaire containing the bio-data of the respondents and 10 items eliciting
responses on the topic was used. The instrument was validated by experts with a reliability coefficient of 0.87. Data
collected were analyzed using descriptive statistics of mean and percentage to answer the research questions while
inferential statistics of chi-square $\left(X^{2}\right)$ and t-test were used to test the hypotheses at 0.05 level of significance.
Findings revealed a significant influence of social networking on students' learning of Business studies and a
significant difference in the mean responses of male and female students on the influence of social media. It was
concluded that social media has highly contributed towards effective learning of business subjects in Ikorodu Local
Government Area of Lagos State. Also, gender influences the use of social media. It was recommended among others
that there should be adequate provision of social media facilities by the government for all senior schools to cater for the
need of the students and enhance effective teaching; students should be allowed to have access to available social media
in the schools such as computers and internet so that they will be familiar with the usage in the school system.
KEYWORDS: Social Media, Business Studies, Gender, Learning, Senior Secondary School.

\section{INTRODUCTION}

In today's society, especially our generation, social media has become a part of our everyday lives. We have access to all types of information in the palm of our hands through our cellphones, iPads and other handheld devices. They can provide us with a weather forecast in ten seconds or less, e-mails, banking, and most importantly, social media. Social media, such as Facebook, Twitter, etc., has taken the technology world to a whole new level (Tara, 2016).
Amadi \& Ewa (2018), in an overview of social media, noted that it has emerged as a term frequently used (and variously defined) to describe different types of communication platforms and electronic ways of interacting. According to Kietzmann (2012), social media is that means that employs mobile and web based technology to create highly interactive platforms via which individuals and community share, co-create, discuss and modifies user-generated content It is a website that does not just give you information but 


\section{SJIF Impact Factor 2021: 8.013| ISI I.F.Value:1.241| Journal DOI: 10.36713/epra2016 ISSN: 2455-7838(Online) EPRA International Journal of Research and Development (IJRD)

interact with you while giving you information. It is a group of internet based application that allows the creation and exchange of users generated content.

Academic excellence or achievement plays an important role in an individual placement, be it in the academic institutions or job placement. Due to this, many people are concerned with the ways they can enhance their academic achievement. The role of academic achievement as one of the predictors of one's life success and also in the aspect of academic placement in schools to higher institutions as well as the level of employability in one's career is inevitable (Kyoshaba, 2009).

According to Benson, Filippaios and Morgan (2010), online social network have become increasingly popular in recent years providing a different and user-friendly way to maintain social connections and share information. Social media provides students with a variety of tools for independent work, reflection, construction and collaboration and value resources for using the web as a tool in order to develop their understanding and solve problems, whether in school, at work, or in their private lives. Although today's students are regarded as "net generation students", they only embrace Facebook which they use to connect with people and make new friends. The use of social media in academic activities is far from adequate. Even many lecturers in Nigerian universities are not competent in the use of social media as a teaching tool.

Social media has been with us over time and the effects cannot be overemphasized, especially its use in the classroom. Kist (2012) noted that having social media in the classroom has been a controversial topic for the last several years as many parents and educators have been fearful of the repercussions of having social media in the classroom. As a result, cell phones have been banned from classroom and schools have blocked many popular social media websites. However, despite adult's apprehensions, students are using social media as schools have realized that they need to incorporate these tools into the classroom and rules are changing.

For instance, The Peel District School Board (PDSB) in Ontario in 2013 PDSB introduced a "Bring Your Own Device" (BYOD) policy and have unblocked many social media sites. Fewkes and McCabe (2012) have researched about the benefits of using Facebook in the classroom. They noted that in early 2013, Steve Joordens, a professor at the University of Toronto, encouraged the 1,900 students enrolled in his introductory psychology course to add content to Wikipedia pages featuring content that related to the course as he argued that the assignment would not only strengthen the site's psychology-related content, but also provide an opportunity for students to engage in critical reflection about the negotiations involved in collaborative knowledge production. However, Wikipedia's all volunteer editorial staff complained that the students' contributions resulted in an overwhelming number of additions to the site, and that some of the contributions were inaccurate. Also, Tara (2016) noted that although we see how it can serve as a positive thing by being a good source of communication, it can also serve as a negative thing such as cyber bullying and the new phrase "cat fishing..

Rabiu (accessed 2021) sees Business Studies as a subject which provides us with the knowledge, understanding and skills needed for productive work or activity. Productive activity involves using business resources to make goods and services that satisfy human needs and wants. Business studies can also be regarded as the study of the methods and techniques of setting up and running a business venture profitably. Business studies learning is important because according to Rabiu (2021), it teaches students how to establish and run businesses (private or public) efficiently; it develops and prepares students for office occupations in future; it equips students with the basic skills with which to begin an occupation, if they do not have an opportunity for further training; it allows students to understand the necessity for the existence of various businesses whereby students are able to differentiate between types of businesses, and it enable students to develop keen interest in various forms of business which they can engage in (set up) after leaving school. The key components or branches of business include Office Practice, Commerce, Book-keeping, Shorthand and Keyboarding.

Social networking sites have been noticed to influence students' learning greatly. For instance, Lau (2012) reported that online social networks help initiate learning activities among students. Students who use online social networks can develop their knowledge based on extensive communications and knowledge sharing from the social network sites. Williams (2008) noticed that the current generations of teens live in a fast-paced technological world with many different types of communication happening all at the same time. For example, he or she may be on the computer on a SNS, while also talking on the phone, sending instant messages to a friend, and emailing someone else all at the same time. Nicole-Ellison (2007) affirmed that teens and teenagers have especially recognized these internet sites to be able to contact their peers, 


\section{SJIF Impact Factor 2021: 8.013| ISI I.F.Value:1.241| Journal DOI: 10.36713/epra2016 ISSN: 2455-7838(Online) EPRA International Journal of Research and Development (IJRD)

share information, reinvent their personas, and showcase their social lives. Facebook represents a potentially useful tool in educational contexts, allowing for both asynchronous and synchronous open dialogue via a familiar and regularly accessed medium; supports the integration of multimodal content such as student-created photographs and video and URLs to other texts, in a platform that many students are already familiar with. It also allows students to ask more minor questions that they might not otherwise feel motivated to visit a professor in person during office hours to ask (Moody 2010). It also allows students to manage their own privacy settings, and often work with the privacy settings they have already established as registered users. It is one alternative means for shyer students to be able to voice their thoughts in and outside of the classroom. It allows students to collect their thoughts and articulate them in writing before committing to their expression. Further, the level of informality typical to Facebook can also aid students in self-expression and encourage more frequent student and-instructor and student-and-student communication.

Twitter promotes social connections among students as it can be used to enhance communication building and critical thinking. Junco, Heibergert, and Loken (2011) in Tara (2016) completed a study of 132 students to examine the link between social media and students' engagement and social media and grades and found that students in the Twitter group had higher GPAs and greater engagement scores than the control group. Gao, Luo, and Zhang (2012) reviewed literature about Twitter published between 2008 and 2011 and concluded that Twitter allowed students to participate with each other in class (back channel), and extend discussion outside of class. They also reported that students used Twitter to get up-to-date news and connect with professionals in their field. Moran, Seaman and Tinti-Kane (2012) observed that YouTube is the most frequently used social media tool in the classroom as students can watch videos, answer questions, and discuss content. They can also create videos to share with others. Eick and King (2012) found that videos kept students' attention, generated interest in the subject, and clarified course content.

Junco's (2012) study on "Too much face and not enough books: The relationship between multiple indices of Facebook use and academic performance" found that time spent on Facebook and checking Facebook were negatively related to overall GPA, and time spent on Facebook is slightly negatively related to time spent studying. In addition, the ability of time spent on Facebook to significantly predict overall GPA shows that there may be negative academic effects for students who use Facebook in certain ways. Paul, Baker, Cochran (2012) researched on effect of online social networking on students' academic performance and found a statistically significant negative relationship exists between time spent by students on OSN and their academic performance as time spent on OSN is shown to negatively impact academic performance. As time spent on social networking sites increases, the academic performance of the students is seen to deteriorate.

On the influence of gender influence on usage of social media, it has been observed that results are mixed as to which group spends more time on the Internet as well as on social media networks. Studies have shown that boys have been online more than girls in previous decades because of earlier forms of technology such as video or computer games (Lin \& Subrahmanyam, 2007).

According to most research done on the topic, the number of teenage girls and boys who communicate on these social media networks are equally divided. Research has shown that though girls and boys are both likely to have a SNS account, the reasons for the accounts may vary based on gender. For girls, social networking sites are primarily placed to reinforce preexisting friendships; for boys, the networks also provide opportunities for flirting and making new friends, however, boys are more likely to create an account simply because they are trying to meet a significant other, or because they are already in a relationship with someone who has requested them to join (Bonds-Raacke \& Raacke, 2008). In a recent study, it was shown that boys seem to benefit more from social media use and communication technology than girls do (Peter \& Valkenburg, 2009).

Merten and Williams (2009) noted that girls are more likely than boys to share personal information about their daily lives as their recent study involving Facebook, MySpace, and Xanga showed that though most teenagers aged 13-17 used these sites for fun and positive reasons, $55 \%$ of girls shared personal stories about depression, anxiety, and relationship problems. Only $15 \%$ of boys shared any personal information besides their hobbies, interests, and friendships. It was also found that adolescents use SNS when dealing with a death of a peer, and use forums and member profiles to help their grieving process.

As regards the use of social media in schools, social media networks, as well as other new forms of communication technology, are also a concern to many school professionals because of the level of distraction 


\section{SJIF Impact Factor 2021: 8.013| ISI I.F.Value:1.241| Journal DOI: 10.36713/epra2016 ISSN: 2455-7838(Online) EPRA International Journal of Research and Development (IJRD)

they create within the school (Greenfield \& Subrahmanyam, 2008). Even though many schools have created many strict rules that forbid the use of handheld technology during school activities or that block certain social networking websites, many students are still able to connect during lecture hours as they please. This has caused distractions during instruction time and has had a negative impact on the learning environment.

\section{STATEMENT OF THE PROBLEM}

In spite of the advantages to the use of social media in the classroom, it has been observed that students' learning is being much affected because too much time is dedicated to the social media at the expense of their studies. Khan (2009) observed that social media users often time experience poor performance academically. Similarly, Englander, Terregrossa and Wang (2010) posit that social media users devoted lesser time to their studies in comparison to non-users did. It has been observed that students' learning is facing a lot of neglect and challenges as students at every educational level are being distracted and seem to devote more attention to social media than they do to their studies which have impacted on their academic performance. Students spend their time chatting and making friends via the social media than they focus on their studies.

\section{PURPOSE OF THE STUDY}

The study investigated the influence of social media on:

1. Senior Secondary School students' learning of business subjects in Ikorodu Local Government Area of Lagos State and

2. ascertained the extent to which gender influences the use of social networking.

\section{RESEARCH QUESTIONS}

1. In what ways does social networking influence students' learning of business subjects?

2. Does gender influence the use of the social media among senior secondary school students?

\section{RESEARCH HYPOTHESES}

1. Social networking does not have significant influence on students' learning.

2. Gender has no significant influence on senior secondary school students' use of social media.

\section{RESEARCH METHOD}

The research design adopted for the study was a descriptive survey. The population of the study consisted of all the students in Commercial class from Senior Secondary Schools in five secondary schools in Ikorodu Local Government Area of Lagos State. The sample for the study was 100 respondents selected through the simple random sampling technique. The instrument for data collection for the study was the questionnaire containing two sections: Section A dealt with respondents' bio-data while section $\mathrm{B}$ dealt with items to which respondents were to give their opinion, in the Likert scale of SA - Strongly Agree; A - Agree, D - Disagree and SD - Strongly Disagree, containing 10 items in all. Content and face validity structures of the instrument were ensured by experts in the department of Business Education. The reliability of the instrument was also ensured and a reliability coefficient of 0.87 was obtained which implies high reliability of the instrument. Data collected were analysed. For the research questions, frequency and percentages were adopted in the presentation and analysis of the data generated for the study. t-test and chi-square statistics were used for testing the research hypotheses at 0.05 level of significance. 


\section{SJIF Impact Factor 2021: 8.013| ISI I.F.Value:1.241| Journal DOI: 10.36713/epra2016 ISSN: 2455-7838(Online) EPRA International Journal of Research and Development (IJRD) \\ Volume: 6 | Issue: 6 | June 2021 \\ - Peer Reviewed Journal}

RESULTS

Research Question 1: In what ways does social networking influence students' learning of business subjects?

Table 1: Influence of social networking on students' learning of Business Studies Mean greater than 2.50 'Agreed' otherwise 'Disagreed'

\begin{tabular}{|c|c|c|c|c|c|c|c|}
\hline$S / N$ & Items & SA & $\bar{A}$ & D & SD & Mean & Decision \\
\hline 1. & $\begin{array}{l}\text { It helps me to gain more relevant } \\
\text { information }\end{array}$ & $\begin{array}{l}20 \\
(20 \%)\end{array}$ & $\begin{array}{l}30 \\
(30 \%)\end{array}$ & $\begin{array}{l}30 \\
(30 \%)\end{array}$ & $\begin{array}{l}20 \\
(20 \%)\end{array}$ & 2.50 & Agreed \\
\hline 2. & $\begin{array}{l}\text { It gives me opportunity for formal } \\
\text { learning. }\end{array}$ & $\begin{array}{l}10 \\
(10 \%)\end{array}$ & $\begin{array}{l}65 \\
(65 \%)\end{array}$ & $\begin{array}{l}10 \\
(10 \%)\end{array}$ & $\begin{array}{l}15 \\
(15 \%)\end{array}$ & 2.75 & Agreed \\
\hline 3. & $\begin{array}{l}\text { It facilitates my learning and skill } \\
\text { development outside school. }\end{array}$ & $\begin{array}{l}40 \\
(40 \%)\end{array}$ & $\begin{array}{l}50 \\
(50 \%)\end{array}$ & $\begin{array}{l}10 \\
(10 \%)\end{array}$ & $0(0 \%)$ & 3.20 & Agreed \\
\hline 4. & $\begin{array}{l}\text { It has helped me to improve my } \\
\text { performance academically. }\end{array}$ & $\begin{array}{l}45 \\
(45 \%)\end{array}$ & $\begin{array}{l}40 \\
(40 \%)\end{array}$ & $\begin{array}{l}15 \\
(15 \%)\end{array}$ & $0(0 \%)$ & 3.15 & Agreed \\
\hline 5. & $\begin{array}{l}\text { It has improved my ability to } \\
\text { search for information. }\end{array}$ & $\begin{array}{l}27 \\
(27 \%)\end{array}$ & $\begin{array}{l}50 \\
(50 \%)\end{array}$ & $\begin{array}{l}15 \\
(15 \%)\end{array}$ & $8(8 \%)$ & 2.96 & Agreed \\
\hline
\end{tabular}

The result presented in Table 1 revealed the influences of social networking on students' learning of business studies. Majority of the respondents indicated that social networking helps them to gain information $(50 \%)$, it gives them opportunity for formal learning $(75 \%)$, it facilitates their learning and skill development outside the school (90\%), it has helped them to improve on their performance academically (85\%) and improved their ability to search for information (75\%).
The mean responses in the table are greater than 2.50 which justified that respondents agreed that social media has influence on students' learning of Business studies.

Research Question 2: Does gender influence the use of the social media among senior secondary school students?

Table 2: Gender influence of social media

\begin{tabular}{|c|c|c|c|c|c|c|c|}
\hline $\mathbf{S} / \mathbf{N}$ & Items & SA & $\mathbf{A}$ & D & SD & Mean & Decision \\
\hline 1. & $\begin{array}{l}\text { Male students have access to } \\
\text { social media than the female } \\
\text { students }\end{array}$ & $45(45 \%)$ & $55(55 \%)$ & $0(0 \%)$ & $0(0 \%)$ & 3.45 & Agreed \\
\hline 2. & $\begin{array}{l}\text { Male students outperform their } \\
\text { female counterparts in Business } \\
\text { Studies due to their frequent use of } \\
\text { social media. }\end{array}$ & $45(45 \%)$ & $40(40 \%)$ & $0(0 \%)$ & $15(15 \%)$ & 3.30 & Agreed \\
\hline 3 & $\begin{array}{l}\text { Social media influence female } \\
\text { students negatively than their male } \\
\text { counterparts. }\end{array}$ & $27(27 \%)$ & $50(50 \%)$ & $15(15 \%)$ & $8(8 \%)$ & 2.96 & Agreed \\
\hline 4. & $\begin{array}{l}\text { Female students make use of } \\
\text { social media for leisure and } \\
\text { chatting thereby reducing their } \\
\text { concentration and attention. }\end{array}$ & $40(40 \%)$ & $50(50 \%)$ & $10(10 \%)$ & $0(0 \%)$ & 3.20 & Agreed \\
\hline 5. & $\begin{array}{l}\text { Social media influence both male } \\
\text { and female students' performance } \\
\text { in Business Studies }\end{array}$ & $45(45 \%)$ & $40(40 \%)$ & $15(15 \%)$ & $0(0 \%)$ & 3.15 & Agreed \\
\hline
\end{tabular}

Mean greater than 2.50 'Agreed' otherwise 'Disagreed'

(c) 2021 EPRA IJRD | Journal DOI: https://doi.org/10.36713/epra2016 | www.eprajournals.com |325 | 


\section{SJIF Impact Factor 2021: 8.013| ISI I.F.Value:1.241| Journal DOI: 10.36713/epra2016 ISSN: 2455-7838(Online) EPRA International Journal of Research and Development (IJRD) \\ Volume: 6 | Issue: 6 | June 2021 \\ - Peer Reviewed Journal}

The result of analysis presented in table 4 revealed the extent to which gender influences the use of social media among students. Majority of the respondents $(100 \%)$ indicated that male students have access to social media than the female students, $85 \%$ indicated that male students outperform their female counterparts in Business Studies due to their frequent use of social media, $75 \%$ indicated that social media has negative influence on female students than their male counterparts. They indicated that female students make use of social media for leisure and chatting thereby reducing their concentration and attention.
Thus, $85 \%$ agreed that there is influence of social media on male and female students' learning in Business Studies. The mean response in the table is greater than 2.50 this implies that majority of the respondents agreed that the influence of gender on the use the social media on students' performance in business studies is high.

\section{TESTING OF HYPOTHESES}

$\mathrm{H}_{01}$ : There is no significance influence of social networking on students' learning in Business studies

Table 3: Chi-square of influence of social networking on students' learning

\begin{tabular}{lllll}
\hline & Calculated Value & df & Asymp. Sig. (2-sided) & Table value \\
\hline Pearson Chi-Square & $52.22^{\mathrm{a}}$ & 4 & 0.00 & \\
Likelihood Ratio & 83.91 & 4 & 0.00 & 6.11 \\
Linear-by-linear & 20.18 & 1 & 0.00 & \\
Association & & & & \\
N of Valid Cases & 100 & & &
\end{tabular}

The result of analysis in Table 3 revealed that Chisquare $\left(\mathrm{X}^{2}\right)=52.22, \mathrm{P}<0.05$, was greater than table value of 6.11 which led to rejection of null hypothesis one. This implies that there was significant influence of

social networking on students' learning of Business studies.

$\mathrm{H}_{02}$ : There is no significance difference between the influence of social media on male and female students.

Table 4: t-test statistics for difference in the influence of social media on male and female students

\begin{tabular}{lllllll}
\hline Variables & N & Mean $(\mathbf{X})$ & St. D. & df & t-cal & t-tab \\
\hline Male & 50 & 3.74 & 0.71 & & & \\
Female & 50 & 2.86 & 0.96 & 98 & 2.85 & 1.96 \\
\hline P $<0.05$ (Significant) & & & & &
\end{tabular}

The result presented in table 4 showed that calculated tvalue of 2.85 was greater than the critical $t$-value of 1.96; as such the hypothesis is rejected. This means that there is significant difference in the mean responses of male and female students on the influence of social media. The influence of social network was high on male students than female students.

\section{DISCUSSION}

The study revealed a significant influence of social networking on students' learning of Business studies. This means that the use of social networking sites provide benefits for students. Majority of the respondents indicated that social networking helps them to gain information, gives them opportunity for formal learning, facilitates their learning and skill development outside the school, helped them to improve on their performance academically and improved their ability to search for information. This agrees with Nicole-Ellison (2007) who affirmed that teens and teenagers have especially recognized these internet sites to be able to contact their peers, share information, reinvent their personas, and showcase their social lives.

The finding of the study further showed that was that there is a significant difference in the mean responses of male and female students on the influence of social media. Influence of gender on the use the social media by students is high. The study contradicted the finding of Merten and Williams, (2009) that girls are more likely than boys to share personal information about their daily lives but agrees with Peter and Valkenburg's (2009) study that boys seem to benefit more from social media use and communication technology than girls do. Majority of the respondents in this study indicated that male students have access to social media than the female students, that male students outperform their female 


\section{SJIF Impact Factor 2021: 8.013| ISI I.F.Value:1.241| Journal DOI: 10.36713/epra2016 ISSN: 2455-7838(Online) EPRA International Journal of Research and Development (IJRD)

counterparts in Business Studies due to their frequent use of social media, that social media has negative influence on female students than their male counterparts, among others. Thus, the study concluded that social media influences male students more than female students.

\section{CONCLUSION}

Based on the findings of the study, it was concluded that social media has highly contributed towards effective learning of business studies and equally improve junior secondary school students' performance in the subject.

\section{RECOMMENDATIONS}

The study therefore provides the following recommendation for the study.

1. There should be adequate provision of social media facilities by the government for all junior schools to cater for the need of the students and enhance effective teaching.

2. Students should be allowed to have access to available social media in the school such as computers and internet so that they will be familiar with the usage in the school system.

3. There is need to properly monitor the students in their use of social media so that the aims of introducing it would be achieved.

4. There is need for teachers to be properly trained on how to effectively use the media to enhance effective teaching and learning in the school so that they can guide students to use it correctly.

\section{REFERENCES}

1. Amadi, E. C. \& Ewa, C. J. (2018). An overview of social media on the academic performance of university students in Nigeria. International Journal of Innovative Information Systems \& Technology Research. 6(1), 1 - 14. Jan-Mar. ISSN: 2467-8562.

2. Benson, W. Fillippaios, F. \& Morgan, S. (2010). Changing the face of business education career planning. International Journal of e-business management. $4(1), 20 \quad-33$. DOI10.3316/IJEBMO401020.

3. Bonds-Raacke, J. \& Raacke, J. 2008. MySpace and facebook: Applying the uses and gratifications theory to exploring friend-networking sites. Cyber Psychology and Behavior, 11, 169-174.

4. Eick, C.J. \& King, D.T. (2012). Non-science majors' perceptions on the use of YouTube video to support learning in an integrated science lecture. Journal of College Science Teaching, 42(1), 26-30.

5. Englander F.; Terregrossa, R. A. \& Wang, Z. (2010). Educational Review, 62(1): 85 -96.
6. Fewkes, A. \& McCabe, M. (2012). Facebook: Learning Tool or Distraction? Journal of Digital Learning in Teacher Education, 28(3), Retrieved from http://eric.ed.gov/?id=EJ972449.

7. Gao, F.; Luo, T. \& Zhang, K. (2012). Tweeting for learning: A critical analysis of research on microblogging in education published in 20082011. British Journal of Educational Technology, 43(5), 783-801.

8. Greenfield, P. \& Subrahmanyam, K. (2008). Online communication and adolescent relationships. The Future of Children, 18, 119140. Retrieved from: http://www.futureofchildren.org.

9. Junco, R., Heiberger, G., \& Loken, E. (2011). The effect of Twitter on college student engagement and grades. Journal of Computer Assisted Learning, 27(2), 119-132.

10. Kietzmann, H. (2012). "Social media? Get serious! Understanding the functional building blocks of social media". Business Horizons 54: 241-251.

11. Kist, W. (2012). Class get ready to tweet: Social media in the classroom. Our children. Retrieved from http://files.eric.ed.gov/fulltext/EJ991339.pdf.

12. Kyoshaba $M$ (2009). Factors affecting academic performance of undergraduate students at Uganda Christian University. Retrieved December 4, 2013 from http://mak.ac.ug/documents/Makfiles/theses/Kyosha ba\%2520Martha. Pdf.

13. Khan, U. (2009). "Facebook students underachieve in exams," Daily Telegraph, at http://www.telegraph.co.uk/education/educationne ws/5145243/Facebookstudents-underachieve-inexams.html.

14. Lau (2012). Review of Use of Animation as a Supplementary Learning Material of Physiology Content in Four Academic Years. The Electronic Journal of E-Learning, 10(4), 377-386.

15. Lin, G. \& Subrahmanyam, K. (2007). Adolescents and the net: Internet use and wellbeing.Adolescence, 42(168), 659-675. Retrieved from: http://findarticles.com/p /articles/ mi_m2248/is_168_42/ai_n27483301/

16. Merten, M. \& Williams, A. (2009). Adolescents' online social networking following the death of a peer. Journal of Adolescent Research, 24, 67-90.

17. Moran, M., Seaman, J., \& Tinti-Kane, H. (2012). How today's higher education faculty use social media. Retrieved from http://www.pearsonlearningsolutions.com $/ p d f s /$ pearson-social-media survey-2012-color.pdf.

18. Moody, M. (2010). Teaching Twitter and beyond: Tips for incorporating social media in traditional courses. Journal of Magazine and New Media Research. 11(2), 1-9. Spring.

19. Nicole-Ellison, C. S. (2007). The benefits of Face book "Fiends;" Social Capital and College 
SJIF Impact Factor 2021: 8.013| ISI I.F.Value:1.241| Journal DOI: 10.36713/epra2016 ISSN: 2455-7838(Online)

\section{EPRA International Journal of Research and Development (IJRD)}

Volume: 6 | Issue: 6 | June 2021

- Peer Reviewed Journal

Students' Use of Online Social Network Sites.

Journal of Computer Mediated Communication.

20. Paul, J., Baker, H., \& Cochran, J. (2012).

Effect of online social networking on student

academic performance. Elsevier, 1, 2118-

2119:2123. Retrieved from

http://www.elsevier.com/locate/comphumbeh

21. Peel District School Board. (2014) BYOD.

Retrieved from http://www.peel schools.org /aboutus/21stCentury/byod/Pages/default.aspx

22. Peter, J. \& Valkenburg, P. (2009). Social consequences of the internet for adolescents: A decade of research.Psychological Science, 18(1), 14.

23. Rabiu, I. M. (accessed 2021). Business Studies JSS 1. file:///C:/Users/User/Downloads/ BUSINESS_STUDIES_JSS_1.pdf

24. Tara, M. H. (2016). The effects of social media use in undergraduate students. Theses and Dissertations. Rowan Digital Works.

25. Williams, A., Boyd, S., Densten, R., Chin, D, Diamond, \& Morgenthaler, C. (2009). "Social Networking Privacy Behaviors and Risks", In Proceeding of CSIS Research Day, Seidenberg School of CSIS, Pace University, USA.

26. Wise, B. (2009). Adolescent literacy: The cornerstone of student success. Journal of Adolescent and Adult Literacy, 52, 369-375. 